\title{
The Role of "Samruk-Kazyna" Sovereign Wealth Fund in Implementation of State Programs of the Republic of Kazakhstan
}

\author{
G. Sansyzbayeva ${ }^{1} \&$ Zh. Ametova ${ }^{1}$ \\ ${ }^{1}$ The High School of Economics and Business of the KazNU named after Al-Farabi, Kazakhstan \\ Correspondence: G. Sansyzbayeva, The High School of Economics and Business of the KazNU named after \\ Al-Farabi, Kazakhstan. E-mail: judi_a@mail.ru
}

Received: November 19, 2014

doi:10.5539/ass.v11n2p1

\author{
Accepted: November 27, 2014 Online Published: December 20, 2014 \\ URL: http://dx.doi.org/10.5539/ass.v11n2p1
}

\begin{abstract}
One of the most important conditions of realization by the state of its functions is a formation of an effective policy in the field of management of the state assets. The role and scales of the state's participation in this process, degree and methods of its influence on production are covered in this article.
\end{abstract}

Keywords: Samruk-Kazyna sovereign wealth fund, the Republic of Kazakhstan, national projects, state strategy

\section{Introduction}

Government regulation of economy is carried out in every single country, regardless of its economic structure. At various stages of development, possibilities of regulation of economy are used in different ways according to influence of external and internal conditions and factors. In the era of globalization states are compelled to apply the principles of competitiveness and, therefore, choose the effective economic policy promoting dynamic rate of the implemented reforms, productive approach to leveling of crisis manifestations.

For providing a more effective economic development under the conditions of departure from directive and command system and transfer to market and liberal system it is necessary for the government to find an optimum correlation between state and market methods of management. In this correlation it is necessary to use positive moments of these opposing, in their native, models and consider the available world experience of functioning of institutes for development or sovereign wealth funds.

The countries with underdeveloped economy become more vulnerable for external circumstances, and the choice of own model in dynamic conditions of the global market demands revision of strategy, which can become competitive in prevention of threats of external economic influence and will promote steady industrial and innovative development.

\section{Main Part}

Samruk-Kazyna Sovereign Wealth Fund of the Republic of Kazakhstan is created in order to increase competitiveness and stability of national economy and anticipate factors of possible negative influence of changes in the world markets on economic growth in the country. A main objective of the Fund's activity is a management of the stock of shares (participation interests) of the national companies belonging to Fund on the property right for maximizing of their long-term value and increasing of competitiveness in the world markets.

Kazakhstan created the National Welfare Fund, the government stated that "Samruk-Kazyna" will contribute to the modernization of the republic's economy and attract foreign investors. Created in the image and likeness of funds in Singapore and Malaysia, "Samruk-Kazyna" is one of the pillars of the political-economic system of President Nursultan Nazarbayev. The Fund monitors the work of nearly 600 members of its system of state companies involved, among other things, oil and gas ("KMG"), railways ("KTZ"), Telecommunications ("Kazakhtelecom"), energy ("Kazatomprom"), government Air Freight ("Air Astana") and mail ("Kazpost"). In 2013, the fund announced a profit of 3.5 billion dollars. Overall, the share of "Samruk-Kazyna" accounts for about 45 percent of the Kazakh economy. In 2012, the fund was divided into two entities: the profitability of the company remained under the control of the Fund "Samruk-Kazyna", which is administered should be optimized, and the costs for two years reduced by 467 million dollars. The second structure, the state holding "Baiterek", will focus on the management of the National Institutes of economic development, such as the Development Bank of Kazakhstan and the Investment Fund. Under this program, during 2014-2015, "Samruk-Kazyna" will 
pass into private hands over a hundred of their enterprises (in the words of the chairman of the fund, the number of them will be more than two hundred).

The reform program is widely welcomed by officials and state-controlled media. The experts also have doubts. "We need deep, comprehensive structural reforms, rather than superficial changes such as those that now occur in" SK "- said one executive, who spoke on condition of anonymity because of their affiliation to the fund. He also added that the program is based on a standardized, top-down, approach, which would be difficult to implement in the face of many fund companies.

Joint Stock Company Sovereign Wealth Fund «Samruk-Kazyna» was founded in accordance with the Decree of President of the Republic of Kazakhstan dated October 13, 2008 № 669 «On some measures on competitiveness and sustainability of national economy» and by the Decree of the Government of the Republic of Kazakhstan dated October 17, 2008 № 962 «On measures on realization of the Decree of President of the Republic of Kazakhstan № 669» by merge of two joint stock companies Kazakhstan Holding for the Management of State Assets SAMRUK and KAZYNA Sustainable Development Fund.

The Development strategy for 2012-2022 was worked out by the Department of strategy development of JSC "Samruk-Kazyna".

The draft Strategy was approved by the Fund's Boards of directors on May 26, 2012 and by the Management Council of the National Welfare Fundchaired by the President of the Republic of Kazakhstan on June 28, 2012. The Development strategy of JSC "Samruk-Kazyna" for 2012-2022 was approved by Decree of the Government of the Republic of Kazakhstan \#1202 dated 14 September, 2012.

The only shareholder of "Samruk-Kazyna" JSC is the Government of the Republic of Kazakhstan. The structure of Fund's group includes the companies from key sectors of economy, including oil and gas, electrical and power, transport, telecommunication and others. The group of companies includes 599 organizations, among them corporate center "Samruk-Kazyna" JSC, 454 subsidiary organizations of all levels and 145 associated and joint organizations, financial investments, including the legal entities and banks which aren't belonged to Fund's group according to the Law of RK "On Sovereign Wealth Fund".

The investment portfolio of "Samruk-Kazyna" JSC includes 138 projects approximately amounted to 139 billion dollars. One of the key directions of investment activity of "Samruk-Kazyna" JSC consists in implementation of the investment projects included in Republican and Regional Cards of industrialization within the State program on the forced industrial innovative development of the Republic of Kazakhstan for 2010-2014. Therefore, "Samruk-Kazyna" JSC accounts for 42\% (34 billion dollars) of the total amount of the program (81 billion dollars), with creation of 21 thousand permanent workplaces. In 2013 the Fund's group of companies had implemented 30 investment projects by a total cost of 30.9 billion dollars.

Despite a positive trend in increase of the general level of corporate management in the Fund's companies in investment activity there is a number of the factors constraining its efficiency, including "individual", but not "portfolio" nature of management of investment projects; absence of indicators of efficiency at level of a portfolio; dependence on raw material prices and antimonopoly regulation, performing of noncommercial functions by Fund's group of companies, including socially oriented functions which constrain the investment potential of the Fund. In 2005-2012 obligations of some subsidiary organizations increased to limits due to considerable volume of investments. In this connection, it is necessary to optimize a debt structure and interest costs of these companies.

Regarding the results of analysis of external and internal environment the following strengths, weaknesses, opportunities and threats of the Fund are revealed:

\section{Strengths:}

1. Active support of the Government of the Republic of Kazakhstan.

2. Existence of the legislation vesting Fund with authority.

3. Existence of a credit rating at level of the sovereign.

4. The projects with important social and economic value, but low profitability have financial support from the state.

\section{Weaknesses:}

1. Existence of non-core assets in structure of some Fund's companies.

2. High leverage of the Fund's companies. 
3. Decline in efficiency of activity due to noncommercial stress on Fund and companies' activity.

4. Disadvantages of personnel policy, including frequent rotation of management of the Fund's group of companies.

\section{Opportunities:}

1. Growth of world demand for raw materials, production and services, oil price increase.

2. Increase in trade opportunities owing to integration processes.

3. Attraction of foreign investments owing to economic growth in the countries of BRIC.

4. The state policy aimed at the development of economy and attraction of foreign investments.

\section{Threats:}

1. The instability in the world financial markets leading to appreciation of the borrowed capital and instability of raw material prices.

2. Change of the legislation (increase in export duties, increase of taxes, etc.).

The key purpose of the Fund is an addition of long-term value of the companies which reached the best world practices. Activity of the Fund's companies has to meet such criteria as high operational efficiency, productivity and profitability, high financial stability, high innovative level of development, transparent and optimum structure of assets.

For achievement of the target goal the Fund stimulates the companies to improvement of financial and production efficiency by means of benchmarking. The comparative analysis of the companies' activity with the leading world companies, analogs and leaders in their field, will become the main instrument of stimulation of the Fund's companies to achievement of the purpose for maximizing of long-term value. The focal point will be placed on increase of such indexes, as profitability and labor productivity. Focus of the companies on indexes of profitability and productivity will promote rapid growth of their long-term value. Along with financial performance, the attention will be focused on use of set of natural and technical and quality indexes of activity for their approximation to the analogous leading regional and world companies.

Table 1. Efficiency of financial indexes

\begin{tabular}{lllllllll}
\hline Index (2011) & Units & "KMG" & CNPC & Sinopec & Repsol & OMV & TNK-BP & $\begin{array}{l}\text { Gazprom } \\
\text { Neft }\end{array}$ \\
\hline ROACE & $\%$ & 12.54 & 7.48 & 13.72 & 6.86 & 9.02 & 35.45 & 19.93 \\
EBITDA margin & $\%$ & 15.7 & 8.79 & 6.90 & 14.18 & 12.36 & 24.47 & 20.65 \\
$\begin{array}{l}\text { Labor productivity } \\
\begin{array}{l}\text { Mabor productivity on } \\
\text { oil production, }\end{array}\end{array}$ & 31.5 & 34.9 & 154,7 & 261.9 & 167.6 & 192.0 & 99.8 \\
tons/person & tonserson & 602 & $\mathrm{n} / \mathrm{a}$ & $\mathrm{n} / \mathrm{a}$ & $\mathrm{n} / \mathrm{a}$ & $\mathrm{n} / \mathrm{a}$ & 3324 & 2810 \\
\hline
\end{tabular}

Source: Development strategy of “Samruk-Kazyna" sovereign wealth Fund” JSC for 2012-2022

Table 2. Efficiency of financial indexes

\begin{tabular}{|c|c|c|c|c|c|c|c|}
\hline Indicator (2010) & Units & $\begin{array}{l}\mathrm{NC} \text { "KTZ" } \\
\text { JSC }\end{array}$ & UnionPacific & $\begin{array}{l}\text { Canadian } \\
\text { National }\end{array}$ & SNCF & DeutscheBahn & RR \\
\hline$\overline{\mathrm{ROE}}$ & $\%$ & 9.1 & 15.7 & 18.7 & 10 & 7.4 & 11.5 \\
\hline $\begin{array}{l}\text { EBITDA } \\
\text { margin }\end{array}$ & $\%$ & 28 & 45 & 46 & 10 & 14 & 26 \\
\hline $\begin{array}{l}\text { Labor } \\
\text { productivity }\end{array}$ & $\begin{array}{l}\text { thous. } \\
\text { KZT/person }\end{array}$ & 4,059 & 58,154 & 55,522 & 24,833 & 26,481 & 6,321 \\
\hline
\end{tabular}

Source: Development strategy of "Samruk-Kazyna" sovereign wealth Fund” JSC for 2012-2022

Thus, at the present time, "NC "KazMunayGas" JSC (hereinafter referred to as "KMG" JSC) is included into a number of the 50 largest oil and gas companies of the world. Therefore, on the proven recoverable oil reserves for the beginning of 2012 the company is on 25-27 place, on output of oil regarding the results of 2011 is on 
35-39 place, on oil refining volume regarding the results of 2011 it is on 40-42 place, on indicators of reserves and gas capacity-is lower than on the 70th place. On indexes of economic efficiency, including an indicator of ROACE, EBITDA margin and labor productivity, "KMG" JSC is in limits of range of the corresponding values of other vertically integrated companies.

The comparative analysis of production and financial indexes of activity of "NC "Kazakhstan temir zholy" JSC with five leading railway companies.

Table 3. «KEGOC» JSC

\begin{tabular}{llllllll}
\hline Index (2011) & Units & $\begin{array}{l}\text { "KEGOC" } \\
\text { JSC }\end{array}$ & $\begin{array}{l}\text { FGC } \\
\text { UES } \\
(2010)\end{array}$ & RedEléctricadeEspaña & $\begin{array}{l}\text { Western } \\
\text { Power } \\
\text { Australia }\end{array}$ & Fingrid & Terna \\
\hline ROACE & $\%$ & 5.24 & $\mathrm{n} / \mathrm{a}$ & 5.8 & $\mathrm{n} / \mathrm{a}$ & 6 & $\mathrm{n} / \mathrm{a}$ \\
$\begin{array}{l}\text { EBITDA Margin } \\
\text { Labor }\end{array}$ & $\begin{array}{l}\% \\
\text { thous. }\end{array}$ & 29.7 & 61.5 & 21.3 & $\mathrm{n} / \mathrm{a}$ & 30 & 75.2 \\
productivity & $\begin{array}{l}\text { KZT/person } \\
\text { Labor }\end{array}$ & 12,053 & 29,470 & 175,493 & 54,667 & 318,128 & 112,133 \\
productivity & $\mathrm{kWh}$ /person & 9.1 & 20 & 146.9 & 5.14 & 241.3 & 100.61 \\
$\begin{array}{l}\text { System Average } \\
\text { Interruption }\end{array}$ & Min. per & 65.7 & $\mathrm{n} / \mathrm{a}$ & 101 & & & \\
$\begin{array}{l}\text { Duration Index } \\
\text { (SAIDI) }\end{array}$ & year & & & & 217 & 286 & 65 \\
$\begin{array}{l}\text { System Average } \\
\text { Interruption }\end{array}$ & Interup. per & 0.2 & $\mathrm{n} / \mathrm{a}$ & 1.9 & & & \\
$\begin{array}{l}\text { Frequency Index } \\
\text { (SAIFI) }\end{array}$ & year & & & & 2 & 6 & 2.8 \\
\hline
\end{tabular}

Source: Development strategy of "Samruk-Kazyna" sovereign wealth Fund" JSC for 2012-2022

"Samruk-Energy" JSC

The comparative analysis with the foreign advanced companies of electrical power sector having a number of characteristics, similar to "Samruk-Energy" JSC, are as follows: KEPCO (South Korea), Vattenfall (Sweden), CEZ Group (Czech Republic), TransAltaCorporation (Canada), PGE (Poland), WGC-3 (Russia) and DTEK (Ukraine) which are national and world leaders in the field of production and transfer of the electric power.

Table 4. Efficiency of financial indexes

\begin{tabular}{|c|c|c|c|c|c|c|c|c|c|}
\hline Index (2010) & Units & $\begin{array}{l}\text { "S-E" } \\
\text { JSC }\end{array}$ & $\begin{array}{l}\text { KEP } \\
\mathrm{CO}\end{array}$ & Vattenfall & $\begin{array}{l}\text { CEZ } \\
\text { Group }\end{array}$ & TransAlta & PGE & DTEK & WGC \\
\hline ROACE & $\%$ & 8.9 & 2.28 & 6.87 & 15.45 & 2.72 & 8.95 & 24.89 & 1.74 \\
\hline EBITDA margin & $\%$ & 21.2 & 28.42 & 44.8 & 34.23 & 33.38 & 25.28 & 4.54 & $\mathrm{n} / \mathrm{a}$ \\
\hline $\begin{array}{l}\text { Labor productivity } \\
\text { on } \\
\text { generation }\end{array}$ & $\begin{array}{l}\text { MWh per } \\
\text { employee }\end{array}$ & 2,062 & 22,000 & 9,876 & 2,097 & 29,463 & 1,657 & 834 & 5,850 \\
\hline $\begin{array}{l}\text { Labor productivity } \\
\text { on coal production }\end{array}$ & $\begin{array}{l}\text { Tons per } \\
\text { employee }\end{array}$ & 5,709 & - & 5,384 & 4,327 & 25,289 & 4,006 & 828 & 293 \\
\hline $\begin{array}{l}\text { Equivalent fuel } \\
\text { consumption for } 1 \\
\mathrm{kWh} \text { electricity } \\
\text { generation }\end{array}$ & $\begin{array}{l}\text { Gramme/1 } \\
\mathrm{kWh}\end{array}$ & 366 & 291 & 310 & 340 & 246 & 367 & 390 & 303 \\
\hline
\end{tabular}

Source: Development strategy of "Samruk-Kazyna" sovereign wealth Fund" JSC for 2012-2022

\section{"NAC "Kazatomprom" JSC}

In the world market of natural uranium mining, "NAC "Kazatomprom" JSC takes the leading positions. At the moment Kazakhstan provides about $25 \%$ of needs for natural uranium in the world and about $35 \%$ of its mining. The comparative analysis with the leading transnational power companies of the world (the French AREVA, the 
Canadian Cameco) indicates relative comparability of indexes of financial efficiency and productivity.

Table 5. Efficiency of financial indexes

\begin{tabular}{|c|c|c|c|c|c|c|c|}
\hline \multirow[b]{2}{*}{ Index (2010) } & \multirow[b]{2}{*}{ Units } & \multirow{2}{*}{$\begin{array}{l}\text { "NAC } \\
\text { "Kazatomprom" } \\
\text { JSC }\end{array}$} & \multicolumn{2}{|c|}{ CAMECO Canada } & \multicolumn{3}{|l|}{ AREVA } \\
\hline & & & Hokding & Uranium & Holding & $\begin{array}{l}\text { Front } \\
\text { End }\end{array}$ & $\begin{array}{l}\text { Minin } \\
\mathrm{g}\end{array}$ \\
\hline \multicolumn{8}{|l|}{ Labor productivity on uranium } \\
\hline Net profit/headcount & $\begin{array}{l}\text { Mln KZT } \\
\text { /person }\end{array}$ & 7.8 & 13.1 & 9.9 & 3,6 & 5,5 & 4,2 \\
\hline $\begin{array}{l}\text { Production } \\
\text { volume/headcount }\end{array}$ & $\mathrm{tU} /$ person & 1.37 & 1.511 & 1.594 & 0.174 & 0.595 & 1.598 \\
\hline $\begin{array}{l}\text { Production volume of } \\
\text { uranium }\end{array}$ & $\mathrm{tU}$ & 9,959 & 8,773 & 8,773 & 8,341 & 8,341 & 8,341 \\
\hline net profit margin & $\%$ & 26 & 24 & 27 & 9 & 11 & 10 \\
\hline
\end{tabular}

Source: Development strategy of "Samruk-Kazyna" sovereign wealth Fund" JSC for 2012-2022

Table 6. "Kazakhtelecom” JSC

\begin{tabular}{|c|c|c|c|c|c|c|c|c|c|}
\hline Index (2010) & Units & $\begin{array}{l}\text { Kazakh } \\
\text { telecom } \\
\text { "JSC }\end{array}$ & $\begin{array}{l}\text { British } \\
\text { Telecom }\end{array}$ & $\begin{array}{l}\text { Deutsche } \\
\text { Telecom }\end{array}$ & $\begin{array}{l}\text { France } \\
\text { Telecom }\end{array}$ & Telstra & $\begin{array}{l}\text { Bell } \\
\text { Canada }\end{array}$ & $\begin{array}{l}\text { Rost } \\
\text { elecom }\end{array}$ & $\begin{array}{l}\text { Sibirt } \\
\text { elecom }\end{array}$ \\
\hline ROIC & $\%$ & 4.79 & 24.25 & 4.11 & 10.22 & 14.34 & 12.04 & 11.21 & 11.17 \\
\hline EBITDA margin & $\%$ & 36.43 & 29.32 & 26.79 & 33.60 & 40.46 & 39.76 & 36.78 & 38.52 \\
\hline $\begin{array}{l}\text { Labor } \\
\text { productivity }\end{array}$ & $\begin{array}{l}\text { thous. } \\
\mathrm{KZT} / \text { pers } \\
\text { on }\end{array}$ & 5,010 & 49,509 & 52,456 & 57,171 & 80,747 & 53,193 & 7,220 & 7,956 \\
\hline $\begin{array}{l}\text { Labor } \\
\text { productivity on } \\
\text { the fixed } \\
\text { communication } \\
\text { lines }\end{array}$ & $\begin{array}{l}\text { Fix.lines/ } \\
\text { employee }\end{array}$ & $12 ., 4$ & 181.1 & 142.9 & 267.3 & 191.5 & 185.0 & 158.9 & 172.5 \\
\hline $\begin{array}{l}\text { Labor } \\
\text { productivity on } \\
\text { Broadband } \\
\text { Access ports } \\
\text { (BBA) }\end{array}$ & $\begin{array}{l}\text { BBA } \\
\text { ports/em } \\
\text { ployee }\end{array}$ & $2 ., 7$ & 243.8 & 65.1 & 81.2 & 94.2 & 58.8 & 34.8 & 17.3 \\
\hline $\begin{array}{l}\text { Density of the } \\
\text { fixed lines of } \\
\text { telecommunicati } \\
\text { on }\end{array}$ & $\begin{array}{l}\text { Fix. } \\
\text { lines/100 } \\
\text { men }\end{array}$ & 23.47 & 29.92 & 43.81 & 70.18 & 40.67 & 27.56 & 20.73 & 3.12 \\
\hline $\begin{array}{l}\text { Subscriber } \\
\text { density of Fixed } \\
\text { Broadband } \\
\text { Access (BBA) }\end{array}$ & $\begin{array}{l}\text { BBA } \\
\text { ports/100 } \\
\text { men }\end{array}$ & 4.73 & 40.27 & 19.96 & 21.32 & 20.00 & 8.76 & 4.54 & 0.31 \\
\hline
\end{tabular}

Source: Development strategy of "Samruk-Kazyna" sovereign wealth Fund” JSC for 2012-2022

Investment activity of the Fund's companies has to promote growth of their long-term value. Therefore, profitability and strategic importance for development of the country have to serve as the key criteria of implementation of investment projects.

Financing of investment projects have to be carried out with the use of various optimum instruments. It may include use of various mechanisms of public-private partnership, including granting the state guarantees, subsidization, rent, concession, etc., and also the budgetary financing of the investment projects initiated by the Government of the Republic of Kazakhstan.

Additional growth of value of the group of companies can be reached due to financing of the projects/companies in new priority sectors. In this case new sectors must provide generation of high income and have the high 
potential of further growth. And for this purpose it is be required to carry out on a constant basis the careful analysis of new opportunities and priority fields both in Kazakhstan, and overseas.

Strategic investments of the Fund have to be directed, first of all, an increase of added value, development of value chain of the existing productions, modernization of infrastructure and development of new sectors.

Table 7. "Kazpost” JSC

\begin{tabular}{|c|c|c|c|c|c|c|}
\hline Index (2010) & Units & $\begin{array}{l}\text { "Kazpost } \\
\text { "JSC }\end{array}$ & $\begin{array}{l}\text { Deutsche } \\
\text { Post }\end{array}$ & $\begin{array}{l}\text { Russian } \\
\text { Post }\end{array}$ & $\begin{array}{l}\text { Australia } \\
\text { Post }\end{array}$ & $\begin{array}{l}\text { Canada } \\
\text { Post }\end{array}$ \\
\hline ROACE & $\%$ & 6.5 & 22.5 & 9.3 & 4.6 & 17.6 \\
\hline EBITDA margin & $\%$ & 10.5 & 5.9 & -5.6 & 13.7 & 11.6 \\
\hline Income per 1 employee & $\begin{array}{l}\text { thous. } \\
\text { KZT/person }\end{array}$ & 1,238 & 23,281 & 1,577 & 86,494 & 15,324 \\
\hline $\begin{array}{l}\text { Share of the written correspondence } \\
\text { delivered on time within the country }\end{array}$ & $\%$ & 99.7 & 94 & 90 & 96 & 95.7 \\
\hline $\begin{array}{l}\text { Share of the parcels delivered on time } \\
\text { within the country }\end{array}$ & $\%$ & 98.6 & 90 & $\mathrm{n} / \mathrm{a}$ & 96.3 & $\mathrm{n} / \mathrm{a}$ \\
\hline
\end{tabular}

Source: Development strategy of "Samruk-Kazyna" sovereign wealth Fund" JSC for 2012-2022

In order to increase share of production of manufacturing industry by Fund's assets and development of value chain, the Fund should increase the volume of the strategic investments aimed at providing growth of repartitions of the operating productions in oil and gas, chemical, mining sectors and engineering.

The Fund should pay special attention on investments in new sectors with a high potential of growth and profitability. Examples of such sectors are pharmaceutics, logistics and transport, alternative power engineering, chemistry and petro-chemistry, projects of development of productions for providing growth of the Kazakhstan contents in purchases of the Fund's companies.

\section{Conclusion}

Existence of Institutes for development is the important lever of controllability the economy in the conditions of crisis overcoming though the fact of their existence isn't defining in management of the state assets yet. The certain strategies assuming accurate, interconnected, system criteria of the managing activity, and also their continuous monitoring and assessment of efficiency are necessary.

Initially institutes for development were created as instruments for implementation of state programs, and in that case profit maximization wasn't a main objective of activity of such companies. However, at a stage of creation of "Samruk-Kazyna" Sovereign Wealth Fund the merger of institutes for development allowed to begin process of introduction of the advanced practice of corporate management in these companies, taking into account the European experience and experience of the similar companies of Singapore, Malaysia, adjust system of planning and budgeting, necessary procedures for increase of efficiency and transparency of the companies' activity.

"Samruk-Kazyna" Sovereign Wealth Fund is created for realization and increase of opportunities and abilities of domestic business for performance of important national tasks in the field of modernization and diversification of the economy, moving the country forward to a new level of social economic development. By means of institutes for development the state has opportunity to participate in the projects focused on creation of complete system of productions which create competitive production consistently developing a technological and economic chain of added values, which will increase competitiveness of a domestic production.

\section{References}

Development strategy of "Samruk-Kazyna" sovereign wealth Fund JSC for 2012-2022.

Geanakoplos, J. (2010). Solving the Present Crisis and Managing the Leverage Cycle. Federal Reserve Bank of New York Economic Policy Review, 16(1), 101-131.

Hamilton, J. D. (1994). Time Series Analysis. Princeton University Press, Princeton, NJ.

Kaminsky, G., Lizondo, S., \& Reinhart, C. (1998). Leading indicators of currency crisis. IMF Staff Paper, 1. http://dx.doi.org/10.2307/3867328

Kane, E. J. (1989). The S\&L Insurance Mess: How Did It Happen? Urban Institute Press, Washington, D.C. 
The annual report for 2013 of "Samruk-Kazyna" Sovereign Wealth Fund JSC (Vol. I). (2014). Astana.

The law of the Republic of Kazakhstan "On Sovereign Wealth Fund". (2012, February 1).

\section{Copyrights}

Copyright for this article is retained by the author(s), with first publication rights granted to the journal.

This is an open-access article distributed under the terms and conditions of the Creative Commons Attribution license (http://creativecommons.org/licenses/by/3.0/). 